\title{
Seed Invigoration Treatments and Durations on Seedling Parameters of Onion (Allium cepa L cv - Indrayani)
}

\author{
Sura Venkata Nirmal Hruday*, Prashant Kumar Rai, \\ M. Raghavanjaneyulu and V. Vijay Bhaskar Reddy
}

Department of Genetics and Plant Breeding, Naini Agricultural Institute, Sam Higginbottom
University of Agriculture, Technology and Sciences, Prayagraj, UP, India

*Corresponding author

\section{A B S T R A C T}

The present investigation was carried out for Seed invigouration treatments and durations on seedling parameters of onion (Allium cepa L.cv-Indrayani). Analysis of variance for the laboratory data revealed that significance mean sum of squares due to seed priming treatments were observed for all the characters under study. The mean performance of seed

Keywords

Onion and $\mathrm{GA}_{3}$ @ 100ppm, Garlic extract solution @ 1:5

Article Info

Accepted:

17 January 2021

Available Online:

10 February 2021 germination \% ranged from 72.75 to 85 with a grand mean of $81.13 \%$. All the treatments were significantly higher in comparison to control. Among the significant treatments for Root length, Shoot length, Seedling length $(\mathrm{cm})$, Seedling fresh weight $(\mathrm{mg})$ and Seedling dry weight (mg), $\mathrm{T}_{5}\left(\mathrm{GA}_{3} @ 100 \mathrm{ppm}\right)$ (24 hrs) was found significantly higher in comparison to other treatments. The mean performance of seedling vigour index I ranged from 897.00 to 1449.25 with a grand mean of 1190.96 .The mean performance of seedling vigour index II ranged from 200.79 to 327.25 with a grand mean of 277.81 . For seedling vigour index I and II, Treatment, $\mathrm{T}_{5}\left(\mathrm{GA}_{3} @ 100 \mathrm{ppm}\right)(24 \mathrm{hrs})$ was significantly higher in comparison to other treatments. It is concluded from the present investigation of seed treatments with different kind of priming exhibited significant effect on seed germination and seedling characteristics. Seed priming with $\mathrm{GA}_{3} @ 100 \mathrm{ppm}$ for a duration of $24 \mathrm{hrs}$ affected all the characters significantly in laboratory experiment. Thus, seed priming with $\mathrm{GA}_{3} @ 100 \mathrm{ppm}$ for a duration of 24 hrs followed by $\mathrm{T}_{10}$ Garlic extract solution @ 1:5 for the duration of $6 \mathrm{hrs}$ is useful for improving germination and seedling characteristics of onion (Allium cepa L cv.- Indrayani).

\section{Introduction}

Onion (Allium cepa L.) belongs to the family Amaryllidaceae is the most important bulb crop cultivated commercially all over the world and it is the second most important horticultural crop after tomato in the world. Onion is also known as "Queen of the
Kitchen". Onion is used through out year in the form of spices as a condiments and its known for its medicinal values (Sunil pareek, 2017).

The key basis of all pre sowing is to hydrate the seed under controlled conditions, so that they become physiologically active. Onion 
seeds usually have a low quality, resulting in slow and asynchronous germination as well as seeds producing a high number of abnormal seedlings (Borowski and Michałek, 2006).

Seed priming is one of the pre-sowing seed management techniques where the seeds are partially soaked and subsequently dried back for invigorative effect that expresses on field emergence and extend up to yield. Priming applications contribute to significant improvement in seed germination and seedling growth in vegetables (Dursun and Ekinci, 2010; Korkmaz, 2005; Korkmaz and Pill, 2003). Seed Invigouration techniques are to improve standard establishment under suboptimal conditions (Ashraf and Foolad, 2005)

\section{Materials and Methods}

The present research work was carried out in the post graduate laboratory, Department of Genetics and Plant Breeding, Sam Higginbottam university of agriculture technology and sciences seed material comprised of Onion variety Indrayani the treatments were represented as $\mathrm{T}_{0}-\mathrm{Control}, \mathrm{T}_{1^{-}}$ KNO3@2\% for 24 hrs, T2-NACL@ @1\% for 24 hrs, $\mathrm{T}_{3}-\mathrm{KH}_{2} \mathrm{PO}_{4} @ 2 \%$ for 24 hrsT 4 -KI @ $1 \%$ for $24 \mathrm{hrs}, \mathrm{T}_{5} \mathrm{GA}_{3} @$ 100ppmfor $24 \mathrm{hrs}$ $\mathrm{T}_{6}-\mathrm{GA}_{3} @ 50 \mathrm{ppm}$ for 24hrs $\mathrm{T}_{7-}$ cowsurine@1:2for6hrs, T8-light treatment24hrs, T9-Fermentedbuttermilk @ 1:2 for 6hrs, $\mathrm{T}_{10}$ Garlic extract solution @1:5-6hrs, $\mathrm{T}_{11-K i n e t i n-50 p p m}$ for $24 \mathrm{hrs}, \mathrm{T}_{12}$ Tobacco leaf extract@1:2 for-6hrs.

$\mathrm{GA}_{3}$ can be used for breaking the seed dormancy and enhancement in seed germination causes changes in seed coat ultrastructure membrane repair triggering enzyme activity lead to germination $\mathrm{KNO}_{3}$ attributes the potassium ions which improve the water relations which can affect the water potential of seeds and help in imbitition

\section{Results and Discussion}

The results shown in table-1 indicate the parameters i.e., germination $\%$, root length, shoot length $(\mathrm{cm})$, seedling length $(\mathrm{cm})$, fresh weight(g), dry weight(g), vigour index-I, vigour index-II. In the present experiment the suitable seed invigouration treatment is $\mathrm{T}_{5^{-}}$ GA3@100ppm for $24 \mathrm{hrs}$ in the present investigation the best performed seed invigouration treatment is $\mathrm{T}_{5^{-}}$GA3 @ 100ppm for $24 \mathrm{hrs}$ when compared to other treatments and control, followed by $\mathrm{T}_{10^{-}}$garlic extract solution@1:5 for 6 hrs.

Superior results were showed on enhancing the germination and seedling characteristics when onion seeds are treated with $\mathrm{GA}_{3} @ 100 \mathrm{ppm}$ for 6hrscompared to control (Thejeshwini et al., 2018). Superior results were showed on enhancing the germination behaviour and seedling characteristics $\mathrm{GA}_{3} @ 100 \mathrm{ppm}$ for $72 \mathrm{hrs}$ compared to other treatments and control in onion (Anju thakur et al., 2018)

Some authors found that physiological processes of germination in primed seeds might be due to the use of $\mathrm{GA}_{3}$ which helps in breaking seed dormancy and promote faster seed germination in onion (Yarnia and Tabrizi et al., 2012). Increase in germination percentage with $\mathrm{GA}_{3}$ might be due to involvement of $\mathrm{GA}_{3}$ in the activation of cytological enzymes (Padma et al., 2013).

$\mathrm{GA}_{3}$ treated seeds might be attributed to fact that the $\mathrm{GA}_{3}$ help in breaking the seed dormancy which results in early germination due to the diffusion of endogenous gibberlin like substances (Gurung et al., 2014). When $\mathrm{GA}_{3}$ was applied artificially to Crotalaria sessiliflora and Dysophyllaya tabeana seeds dormancy was broken and the seeds are germinated (Kwon et al., 2018). 
Table.1

\begin{tabular}{|c|c|c|c|c|c|c|c|c|c|}
\hline & Treatments & $\begin{array}{c}\text { Germination } \\
\%\end{array}$ & $\begin{array}{c}\text { Root } \\
\text { length } \\
(\mathrm{cm})\end{array}$ & $\begin{array}{l}\text { Shoot } \\
\text { length } \\
\text { (cm) }\end{array}$ & $\begin{array}{l}\text { Seedling } \\
\text { length } \\
(\mathrm{cm})\end{array}$ & $\begin{array}{l}\text { Seedling fresh } \\
\text { weight (mg) }\end{array}$ & $\begin{array}{l}\text { Seedling } \\
\text { dry weight } \\
\text { (mg) }\end{array}$ & $\begin{array}{c}\text { Seedling } \\
\text { vigour } \\
\text { Index I }\end{array}$ & $\begin{array}{l}\text { Seedling vigour } \\
\text { Index II }\end{array}$ \\
\hline 1 & $\mathrm{~T}_{0}$ (Control) & 72.75 & 2.73 & 9.60 & 12.33 & 4.11 & 2.76 & 897.00 & 200.79 \\
\hline 2 & $\begin{array}{l}\mathrm{T}_{1}\left(\mathrm{KNO}_{3} @ 2 \%\right) \\
(24 \mathrm{hrs})\end{array}$ & 77.25 & 3.70 & 10.05 & 13.75 & 4.41 & 3.16 & 1062.18 & 244.11 \\
\hline 3 & $\begin{array}{l}\mathrm{T}_{2} \text { (NACL@1\%) } \\
\text { (24 hrs) }\end{array}$ & 82.00 & 3.95 & 9.93 & 13.88 & 4.52 & 3.29 & 1138.16 & 269.78 \\
\hline 4 & $\begin{array}{l}\mathrm{T}_{3}\left(\mathrm{KH}_{2} \mathrm{PO}_{4} @ 2 \%\right) \\
(24 \mathrm{hrs})\end{array}$ & 80.75 & 4.08 & 11.07 & 15.15 & 4.55 & 3.38 & 1223.36 & 272.93 \\
\hline 5 & $\begin{array}{l}\mathrm{T}_{4}(\mathrm{KI} @ 1 \%)(24 \\
\mathrm{hrs})\end{array}$ & 82.00 & 4.28 & 10.00 & 14.28 & 4.70 & 3.35 & 1170.96 & 274.70 \\
\hline 6 & $\begin{array}{l}\mathrm{T}_{5}\left(\mathrm{GA}_{3} @ 100 \mathrm{ppm}\right) \\
(24 \mathrm{hrs})\end{array}$ & 85.00 & 4.90 & 12.15 & 17.05 & 4.95 & 3.85 & 1449.25 & 327.25 \\
\hline 7 & $\begin{array}{l}\mathrm{T}_{6}\left(\mathrm{GA}_{3} @ 50 \mathrm{ppm}\right) \\
(24 \mathrm{hrs})\end{array}$ & 82.50 & 4.10 & 11.04 & 15.14 & 4.63 & 3.42 & 1249.05 & 282.15 \\
\hline 8 & $\begin{array}{l}\mathrm{T}_{7} \text { (Cows } \\
\text { urine@1:2) (6 hrs) }\end{array}$ & 82.25 & 3.68 & 10.72 & 14.40 & 4.78 & 3.36 & 1184.40 & 276.36 \\
\hline 9 & $\begin{array}{l}\mathrm{T}_{8} \text { (Light } \\
\text { treatment) (24hrs) }\end{array}$ & 84.25 & 3.70 & 10.53 & 14.23 & 4.72 & 3.39 & 1198.87 & 285.60 \\
\hline 10 & $\begin{array}{l}\mathrm{T}_{9}(\text { Fermented } \\
\text { butter milk@1:2) } \\
(6 \mathrm{hrs})\end{array}$ & 84.25 & 4.00 & 10.85 & 14.85 & 4.82 & 3.45 & 1251.11 & 290.66 \\
\hline 11 & $\begin{array}{l}\mathrm{T}_{10} \text { (Garlic extract } \\
\text { solutions@ @ 1:5) } \\
\text { (6hrs) }\end{array}$ & 83.25 & 4.15 & 11.30 & 15.45 & 4.94 & 3.69 & 1286.21 & 307.19 \\
\hline 12 & $\begin{array}{l}\mathrm{T}_{11} \\
\text { (Kinetin@50ppm) } \\
(24 \mathrm{hrs})\end{array}$ & 79.25 & 4.13 & 10.50 & 14.63 & 4.81 & 3.68 & 1159.42 & 291.64 \\
\hline 13 & $\begin{array}{l}\mathrm{T}_{12} \text { (Tobacco leaf } \\
\text { extract@1:2) } \\
(6 \mathrm{hrs})\end{array}$ & 79.25 & 4.10 & 11.20 & 15.30 & 4.75 & 3.64 & 1212.52 & 288.47 \\
\hline & Grand Mean & 81.13 & 3.96 & 10.68 & 14.64 & 4.66 & 3.41 & 1190.96 & 277.81 \\
\hline & S.Em & 1.58 & 0.13 & 0.36 & 0.4 & 0.1 & 0.14 & 42.18 & 12.86 \\
\hline & CD $(5 \%)$ & 4.51 & 0.38 & 1.03 & 1.15 & 0.28 & 0.4 & 120.65 & 36.79 \\
\hline & CV & 3.89 & 6.66 & 6.75 & 5.5 & 4.28 & 8.27 & 7.08 & 9.26 \\
\hline
\end{tabular}

Seed priming with $\mathrm{GA}_{3}$ might cause acceleration of metabolic reactions before germination made germination possible under salinity stress (Wang et al., 2014).

In conclusion the invigouration seed treatments differed significantly with respect to storability of onion seeds. All the invigouration seed treatments are superior over control it is concluded from the present investigation that the seed treatments of onion priming exhibited significant effect on seed germination and seedling characteristics.

Among seed invigouration treatments initially
$\mathrm{GA}_{3}$ treated seeds for a duration of $24 \mathrm{hrs}$ effected maximum germination (85\%), Root length $(4.9 \mathrm{~cm})$, Shoot length $(12.15 \mathrm{~cm})$, Seedling length $(17.05 \mathrm{~cm})$ Seedling fresh weight $(4.95 \mathrm{mg})$, Seedling dry weight (3.85mg), Seedling vigour index-I (1449.25) Seedling vigour index-II (327.25) all the characters significantly in laboratory experiment was followed by Garlic extract solution@1:5 for 6 hrs. Thus, seed priming with GA 3 @100ppm for a duration of 24 hrs was followed by Garlic extract solution@1:5 for $6 \mathrm{hrs}$ is useful for improving germination and seedling characteristics of onion (Allium cepa L cv- Indrayani). 


\section{References}

Ashraf M, FooladM R. (2005). Presowing seed treatment- a shotgun approach to improve germination growth and crop yield under saline and non saline conditions Advances in Agronomy.;88$223-271$

Anjuthakar and Nehasayal (2018) Effects of seed invigouration treatments on seed germination seedling vigour and physio biochemical characteristics of Angelica glauca EDGEW-An endangered medicinal herb International Journal of Bio-resource and Stress Management 9(3): 353-358.

Thejeshwani, B, A MahonarRao, Razia Sultana and N Hanuman Nayak(2018) On farm pre-sowing invigouration seed treatments in onion (Allium cepa L.) Journal of Pharmacognosy and Phytochemistry 7(5): 3354-3357

Borowski E, Michalek S. (2006). The effect of seeds conditioning on emergence and early growth of onion and carrot seedlings. Annales Universitatis Mariae Curie-SkolodowskaSectio EEE, Horticultura.; 16: 119-129.

Dursun A, Ekinci M. (2010). Effects on different priming treatments and priming durations on germination percentage of parsley (Petroselinum crispum L.) seeds Agricultural sciences.;1(1):17-23.
Gurang N, Swamy GSK, Sarkar SK, Ubale NB. (2014). Effect of chemicals and growth regulators on Germination, Vigour and growth of passion fruit (Passiflora edulis Sims.) The Bioscan. 9(1):155-157

Kwon, H.Y. Kim, H.Y., Bae, K.H. and Kim, S.-Y. (2018). Improvement of seed germination in Dysophylla atabeana, a critically endangered plant species in Korea. Seed Science and Technology, 46, 385-392.

Padma Lay, Basvaraju GV, Sarika G, Amuratha N. (2013), Effect of seed treatments to enhance seed quality of papaya (Carica papaya L) cv surya. Global Journal of Biology Agriculture and Health Sciences, 2(3): 221-225.

Sunil Pareek (2017) Onion (Allium cepa L.): Chemistry and Human Health, $2^{\text {nd }}$ Edition Department of Agriculture and Environmental Sciences, National Institute of Food Technology Entrepreneurship and Management (NIFTEM), Kundli, Sonepat, Haryana, India https://www.researchgate.net/ publication/320428763

Wang L., Mu C., Du M., Chen Y., Tian X., Zhang M., Li Z. (2014). The effect of mepiquat chloride on enlongation of cotton (Gossypium hirsutum L) internode is associated with low concentration of gibberellic acid. Plant science 225: 15-23.

\section{How to cite this article:}

Sura Venkata Nirmal Hruday, Prashant Kumar Rai, M. Raghavanjaneyulu and Vijay Bhaskar Reddy, V. 2021. Seed Invigoration Treatments and Durations on Seedling Parameters of Onion (Allium cepa L cv-Indrayani). Int.J.Curr.Microbiol.App.Sci. 10(02): 1908-1911. doi: https://doi.org/10.20546/ijcmas.2021.1002.227 